\title{
A Influência dos Receptores 5-HT3 no Processamento Nociceptivo
}

\author{
Tiago Santos Carvalho \\ Farmacêutico-Bioquímico, Biomédico, Bacharel em Direito, Mestre em Bioquímica e Doutorando em Qualidade Ambiental, \\ Professor Adjunto da Universidade Feevale, Novo Hamburgo-RS, Brasil.
}

A dor é um mal que atinge um número crescente de pessoas em todo o mundo, independentemente de gênero e faixa etária, assim sendo, justificam-se os estudos que procuram abordar os processos envolvidos na sua gênese, buscando compreender as bases científicas responsáveis por este processo.

De acordo com diferentes pesquisadores, a dor é reconhecida, de forma unânime como uma das principais consequências das mais diferentes patologias e sua repercussão é considerada potencialmente prejudicial para o organismo. Além disto, a incômoda sensação causada pela dor representa um importante mecanismo de vigília do organismo, bem como um sinal de alerta para um perigo iminente ${ }^{1}$. Diante deste contexto, o sistema serotoninérgico desempenha relevante função na modulação da dor, sendo que os receptores subtipos $5-\mathrm{HT}_{3}$ possam desempenhar importante papel na transmissão nociceptiva ${ }^{2}$.

Tendo em vista os motivos acima expostos e o expressivo número de trabalhos que trazem resultados controversos a respeito da efetiva participação destes receptores na resposta nociceptiva, a Revista Neurociências apresenta o artigo intitulado "Influência dos Receptores 5- $\mathrm{HT}_{3}$ no Processamento Nociceptivo de Ratos Submetidos ao Teste da Formalina", onde os autores avaliaram a participação da via serotoninérgica na modulação da dor e descreveram a influência dos receptores $5-\mathrm{HT}_{3}$ na resposta nociceptiva de ratos Wistar submetidos ao teste da formalina, propondo, desta forma, um amplo debate e uma investigaçáo mais profunda acerca do assunto em tela ${ }^{3}$.

Os resultados obtidos pelos autores demostraram cientificamente que a administração intraplantar de formalina proporcionou uma redução dos limiares nociceptivos, favorecendo um aumento dos números de elevação da pata dos animais, sendo este comportamento reduzido, durante a segunda etapa dos testes, através da administra- ção de ondansetrona. Além disto, o modelo de nocicepção induzido utilizado pelos autores também permitiu avaliar de forma criteriosa dois tipos distintos de nocicepção, bem como a utilização de fármacos analgésicos ${ }^{3}$.

Pelo exposto no presente trabalho, os autores sugerem que o fármaco administrado agiu de modo a reduzir a dor inflamatória provocada por formalina, possivelmente devido a um processo de interação com mediadores inflamatórios ou através do bloqueio direto de vias nociceptivas. Além disto, evidenciou-se também, com base nos estudos realizados, que existe a participaçáo dos receptores $5-\mathrm{HT}_{3}$ no processamento nociceptivo periférico, sugerindo que a resposta nociceptiva é influenciada diretamente por estes receptores, em especial em resposta à dor inflamatória ${ }^{3}$.

Por fim, ressalta-se a relevante contribuição científica proporcionada pelos resultados apresentados no artigo "Influência dos Receptores 5- $\mathrm{HT}_{3}$ no Processamento Nociceptivo de Ratos Submetidos ao Teste da Formalina”, os quais possibilitaram uma melhor compreensão no instigante mecanismo de processamento e resposta à dor.

\section{REFERÊNCIAS}

1.Rocha A, Kraychet D, Lemonica L, Carvalho L, Barros G, Garcia J, et al. Dor: aspectos atuais da sensibilização periférica e central. Rev Bras Anestesiol 2007;57:94-105.

http://dx.doi.org/10.1590/S0034-70942007000100011

2.Bardin L, Lavarenne J, Eschalier A. Serotonin receptor subtypes involved in the spinal antinociceptive effect of 5-HT in rats. Pain 2000;86:8-11.

http://dx.doi.org/10.1016/S0304-3959(99)00307-3

3.Garcia TA, Nunes AX, Teixeira DG, Ferreira CMR. Influência dos Receptores 5-HT3 no Processamento Nociceptivo de Ratos Submetidos ao Teste da Formalina. Rev Neurocienc 2012;20(4):527-533.

http://dx.doi.org/10.4181/RNC.2012.20.772.7p 